\title{
Associations of multi-decadal sea-surface temperature variability with US drought
}

\author{
Gregory J. McCabe ${ }^{\mathrm{a}, *}$, Julio L. Betancourt ${ }^{\mathrm{b}}$, Stephen T. Gray ${ }^{\mathrm{c}}$, \\ Michael A. Palecki ${ }^{\mathrm{d}}$, Hugo G. Hidalgo ${ }^{\mathrm{e}}$ \\ ${ }^{a}$ US Geological Survey, Denver Federal Center, MS 412, Denver, Co 80225, USA \\ ${ }^{\mathrm{b}}$ US Geological Survey, Desert Laboratory, 1675 West Anklam Road, Tucson, AZ 85745, USA \\ ${ }^{\mathrm{c}}$ Wyoming Office of State Climatology, 1000 East University Avenue, Department 3943, Laramie, WY 82071, USA \\ ${ }^{\mathrm{d}}$ Illinois States Water Survey, 2204 Griffith Drive, Champaign, IL 61820, USA \\ ${ }^{\mathrm{e}}$ Scripps Institution of Oceanography, University of California, San Diego, 9500 Gilman Drive, Mail code 0224, La Jolla, CA 92093, USA
}

Available online 18 July 2007

\begin{abstract}
Recent research suggests a link between drought occurrence in the conterminous United States (US) and sea surface temperature (SST) variability in both the tropical Pacific and North Atlantic Oceans on decadal to multidecadal (D2M) time scales. Results show that the Atlantic Multidecadal Oscillation (AMO) is the most consistent indicator of D2M drought variability in the conterminous US during the 20th century, but during the 19th century the tropical Pacific is a more consistent indicator of D2 M drought. The interaction between El Niño-Southern Oscillation (ENSO) and the AMO explain a large part of the D2M drought variability in the conterminous US. More modeling studies are needed to reveal possible mechanisms linking low-frequency ENSO variability and the AMO with drought in the conterminous US.
\end{abstract}

(C) 2007 Elsevier Ltd and INQUA. All rights reserved.

\section{Introduction}

Droughts of varying frequency, intensity, and duration affect most land areas of the world at some time. In addition, drought is one of the most expensive types of natural disasters in developed societies where a large part of the economy is based on industrial agriculture (FEMA, 1995), and is very costly in terms of human life in societies dependent on subsistence agriculture (FAO, 2004). Because of the potential substantial effects of drought, there have been increased efforts during recent years to monitor drought status (Svoboda et al., 2002), and predict its onset, intensification, or amelioration globally (Goddard et al., 2003). These efforts primarily focus on the occurrence of drought events on temporal scales that range from seasons to years. Climate indices computed from atmospheric

\footnotetext{
*Corresponding author.

E-mail addresses: gmccabe@usgs.gov (G.J. McCabe), jlbetanc@usgs.gov (J.L. Betancourt), sgray8@uwyo.edu (S.T. Gray), palecki@uiuc.edu (M.A. Palecki), hhidalgo@ucsd.edu (H.G. Hidalgo).
}

pressure data or sea-surface temperatures often have specific and quantifiable relations with drought components, such as precipitation, at particular geographic locations. For instance, El Niño and La Niña events of the Southern Oscillation have been associated with changes in precipitation or drought indices in many areas of the world (Walker, 1923; Kousky et al., 1984; Nicholson, 1986; Ropelewski and Halpert, 1986, 1989; Kiladis and Diaz, 1989; Dai and Wigley, 2000; Diaz and Markgraf, 2000; Goodrich, 2007). Many of these forcing-response relations are useful in diagnostic studies; however, the reliability of seasonal predictions based on these relations varies over time and from region to region or is confounded by other forcing factors that may or may not vary independently (Cayan et al., 1998; Cole and Cook, 1998; McCabe and Dettinger, 1999; Rajagopalan et al., 2000).

The uncertainties of drought monitoring and prediction are increased further by the non-stationary nature of drought in many locations. In a study of global Palmer Drought Severity Index (PDSI) values Dai et al. (2004) identified a global mode of spatially coherent trends in 
drought during the 20th Century. Decreasing PDSI values (i.e. increasing drought incidence) are especially apparent during the last 50 years in the Sahel region of Africa and in high-latitude regions of North America and Asia, while increasing PDSI values (i.e. decreasing drought incidence) are apparent in some mid-latitude continental zones in both the Northern and Southern Hemisphere. Changes in air temperature substantially contribute to the drought trends during the latter decades of the period. While a trend mode is identified encompassing the entire 20th Century, it is apparent that some sub-regions represented by this mode, such as the US Great Plains and the central Asian steppe, exhibit reversed drought trends between the periods before and after 1950 (Dai et al., 2004). In addition to natural variations, drought trends may be altered in the future as the climate system adjusts to human-induced changes in global radiative forcing, and the regional nature of these changes is not well established (Allen and Ingram, 2002; Burke et al., 2006). Simulations from 19 general circulation models, based on a moderate carbon dioxide emissions scenario (A1B), generally agree that the subtropics will become drier while the high latitudes become wetter throughout the 21st Century (Lu et al., 2007; Seager et al., 2007). In any case, currently observed trends in global drought patterns may or may not be a reliable predictor of future states.

Multi-year to multidecadal variations have been found in drought and precipitation records of many global regions (Mccabe and Palecki, 2006). Work to reconstruct drought status or seasonal precipitation from tree-ring analysis in North America clearly demonstrates the existence of several periodic and quasi-periodic drought cycles as well as individual events of great severity within the last two millennia (Woodhouse and Overpeck, 1998; Cook et al., 1999, 2004, 2007). Several candidate forcing factors for the variance of drought at decadal to multidecadal time scales have been identified over the last 10 years, including several with Pacific/Indian Ocean and Atlantic Ocean source regions (Enfield et al., 2001; Hoerling and Kumar, 2003; McCabe et al., 2004; Schubert et al., 2004; Seager et al., 2005; Sutton and Hodson, 2005; Cook et al., 2007; Goodrich, 2007). Sea-surface temperature indices that appear to be strongly related to drought in the US are the Pacific Decadal Oscillation (PDO), the Atlantic Multidecadal Oscillation (AMO), and the El Niño/Southern Oscillation (ENSO) (Enfield et al., 2001; Schubert et al., 2004; McCabe et al., 2004; Seager et al., 2005; Cook et al., 2007; Goodrich, 2007). The probabilities of shifts in decadal to multidecadal modes of climate variation can be quantified (Enfield and Cid-Serrano, 2006), and, combined with information about the forcing of these variations, may offer the best opportunity for improving drought forecasts (Sutton and Hodson, 2005).

The PDO (Mantua et al., 1997) represents low frequency changes in the sea surface temperature (SST) patterns of the Pacific Ocean and is computed from SSTs in the North Pacific Ocean north of $20^{\circ}$ North latitude. The PDO is generally correlated with ENSO and incorporates subtle multiple-frequency responses to ENSO as well as responses to extratropical ocean circulation dynamics ( $\mathrm{Gu}$ and Philander, 1997; Alexander et al., 1999; Newman et al., 2003). Thus, some argue that the PDO may be nothing more than a low frequency realization of ENSO. However, the PDO index does not always correlate well with ENSO indices (Mantua et al., 1997), and may explain modulations in the strength of ENSO teleconnections to drought and/or precipitation (Cayan et al., 1998; Cole and Cook, 1998; Gershunov and Barnett, 1998; McCabe and Dettinger, 1999, 2002), and, according to one author, appears to be more than just a manifestation of a red noise process (Rodionov, 2006). It should be noted that Bulic and Brankovic (2006) suggest that changing patterns of ENSO teleconnections in observations is an artifact of poor sampling. For the purposes of examining decadal climate variability, the PDO is useful as a statistical representation of important Pacific Ocean forcing factors at decadal and greater time scales, even if its physical independence from ENSO is only partial.

The AMO is an index of SSTs in the North Atlantic Ocean between the equator and $70^{\circ} \mathrm{N}$ (Enfield et al., 2001). The AMO index is generally computed as a detrended 10year running mean of these SSTs. An alternative AMO definition was based on an analysis of low-frequency global SST modes (Enfield and Mestas-Nuñez, 1999). A single mode represented the entire North Atlantic basin, exhibiting a long-term, quasi-cyclic variation at time scales of 50-70 years that was first noted in the North Atlantic by Schlesinger and Ramankutty (1994). More recent research also reveals that multidecadal variability in North Atlantic climate is dominated by a single mode of SST variability (Sutton and Hodson, 2003; Knight et al., 2006).

There have been a number of findings in the literature identifying influences of low-frequency changes in Atlantic SSTs on drought and precipitation variations in North America (Enfield et al., 2001; McCabe et al., 2004; Shabbar and Skinner, 2004), Africa (Fontaine and Janicot, 1996), Europe (Sutton and Hodson, 2005; McCabe and Palecki, 2006), South America (Carton et al., 1996), and the Caribbean (Giannini et al., 2003). Like PDO and ENSO relations, the relation between the AMO and the dominant mode of atmospheric circulation variability in the Atlantic basin, the North Atlantic Oscillation (NAO), is not completely established, although modeling studies suggest a link between the NAO and North Atlantic SSTs (Peng et al., 2002; Czaja and Frankignoul, 2002). In addition, research has indicated that the North Atlantic may have climatic predictability on the order of a decade or longer (Griffies and Bryan, 1997) which has important implications for climate forecasting.

Low-frequency modes of global SST variability may or may not be independent; meaning that variability in one ocean sector could modulate variability in another. Dima and Lohmann (2007) suggest that variations in the thermohaline circulation (THC) produce uniform SST 
anomalies in the North Atlantic that are associated with a hemispheric sea-level pressure (SLP) pattern that features atmospheric pressure anomalies of opposite signs over the North Pacific and North Atlantic Oceans. This SLP pattern is amplified through atmosphereocean interactions in the North Pacific and subsequently affects ice transport from the Arctic into the North Atlantic and consequently the strength of the THC. This mechanism suggests a link between the variability of the Atlantic, Pacific, and Arctic oceans on D2M time scales.

We offer an additional example that admittedly plays to our own bias that D2M North American hydroclimatic variability in all seasons is at least partly related to the AMO. Multi-model experiments indicate that D2M variability in North and South Atlantic SSTs associated with changes in the THC can modulate ENSO variability (Timmerman et al., in press). Timmermann et al. (in press) suggest that a strong THC leads to a weakening of ENSO variability. Similarly, Dong et al. (2006) show that an enhanced THC produces atmospheric bridging from the tropical Atlantic to the tropical Pacific, which leads to reduced ENSO variability. The opposite also is true. In a companion paper, Dong and Sutton (in press) introduce freshwater perturbations in the North Atlantic, which induce a weakened THC, a North Atlantic cooling/South Atlantic warming dipole, a southward shift in the Intertropical Convergence Zone (ITCZ), enhanced ENSO variance, and stronger asymmetry between El Niño and La Niña. These results are in line with Torrence and Webster's (1998, 1999) observations of a higher ENSO variance before about 1920 and after 1960, and lower ENSO variance from about 1935 to about 1960. These changes in ENSO variance roughly coincide with the characteristic periods of North Atlantic cooling (before 1920 and after 1960) and warming (from the mid-1920s to just after 1960).

This North Atlantic THC modulation of ENSO offers one alternative to the leading theory of decadal ENSO variability on paleo timescales - the ocean dynamical thermostat mechanism of Clement et al. (1996). According to this theory, uniform radiative forcing (heating) over the tropical Pacific causes disproportionate cooling in the eastern tropical Pacific, steepens the east-west SST gradient, and produces persistent La Niña-like conditions; this theory seems to hold up in models of ENSO variability over the last 1000 years (Mann et al., 2005). Radiative forcing (solar and volcanic fluctuations), and not just internal ocean atmosphere interactions, however, also can cause multidecadal fluctuations in North Atlantic SSTs (Shindell et al., 2003), which could modulate ENSO variability (Dong et al., 2006; Dong and Sutton, in press). Given the importance of the tropical Pacific, future discussion of the ultimate sources of North American drought will surely revolve around these two, perhaps compatible hypotheses (AMO vs. the dynamic ocean thermostat model) of ENSO variability.

\section{Decadal-to-multidecadal (D2M) climate variability}

D2M variability, characterized by alternating and widespread droughts and pluvials, is a consistent feature of both instrumental and tree-ring records of hydroclimate in the western United States (US). Some notable examples include the dramatic switch from the megadrought in the late 1500 s to the megapluvial in the early 1600 s, and the bracketing of epic droughts in the 1930s and 1950s by two of the wettest episodes (1905-1920 and 1965-1995) in the last millennium (Woodhouse and Overpeck, 1998). D2M precipitation variability in the western US tends to be spatially coherent, and can synchronize physical and biological processes in ways that are complex and difficult to forecast and monitor (Swetnam and Betancourt, 1998; Siebold and Veblen, 2006; Gray et al., 2006).

There is growing debate about whether D2M variability in western US hydroclimate represents true climatic regimes - i.e., multiple steady states with different statistics and rapid transitions from one state to the other. Loworder persistence can arise in any time series from stationary red-noise processes, and could be misinterpreted as regimes (Rodionov, 2006). D2M variability should not be dismissed summarily, however, based solely on analysis of instrumental records too brief to capture more than a couple of realizations; D2M variability commonly is found in "prewhitened" tree-ring chronologies (Fig. 1). In these reconstructions, climatic regimes can be quantified objectively by removing year-to-year persistence in tree growth (e.g., Biondi et al., 2005), and D2M variability is often statistically significantly greater than what can be expected from red noise processes alone.

In a study of D2M variability in global PDSI values and global SSTs, McCabe and Palecki (2006) found similar D2M signals in both ocean and land-based climate. McCabe and Palecki (2006) examined detrended and 10year smoothed annual global PDSI values and SSTs for the period 1925 through 2003 using principal components analysis (PCA) and singular value decomposition (SVD) to identify the primary modes of multidecadal PDSI and SST variability (Fig. 2). The PCA of the data indicated that two PCs explain approximately $38 \%$ of the variance in the detrended and smoothed PDSI data. The score time series and loadings of these two PCs indicate that these modes of PDSI variability are related to the PDO (and Indian Ocean SSTs) and the AMO. Similarly, a PCA of detrended and 10-year smoothed annual global SSTs indicated that the first two PCs explain nearly $56 \%$ of decadal SST variability. The SST PCs also are highly correlated with the PDO, Indian Ocean SSTs, and the AMO, and more weakly related to NINO3.4 (NINO3.4 SSTs are often used as an index of ENSO conditions (Trenberth, 1997) and are averaged SSTs for the region from $5^{\circ}$ north latitude to $5^{\circ}$ south latitude and from $170^{\circ}$ west longitude to $120^{\circ}$ west longitude). In addition, the PDSI PCs and the SST PCs are directly correlated in a pairwise fashion. The first PDSI and SST PCs reflect variability of the detrended and smoothed 

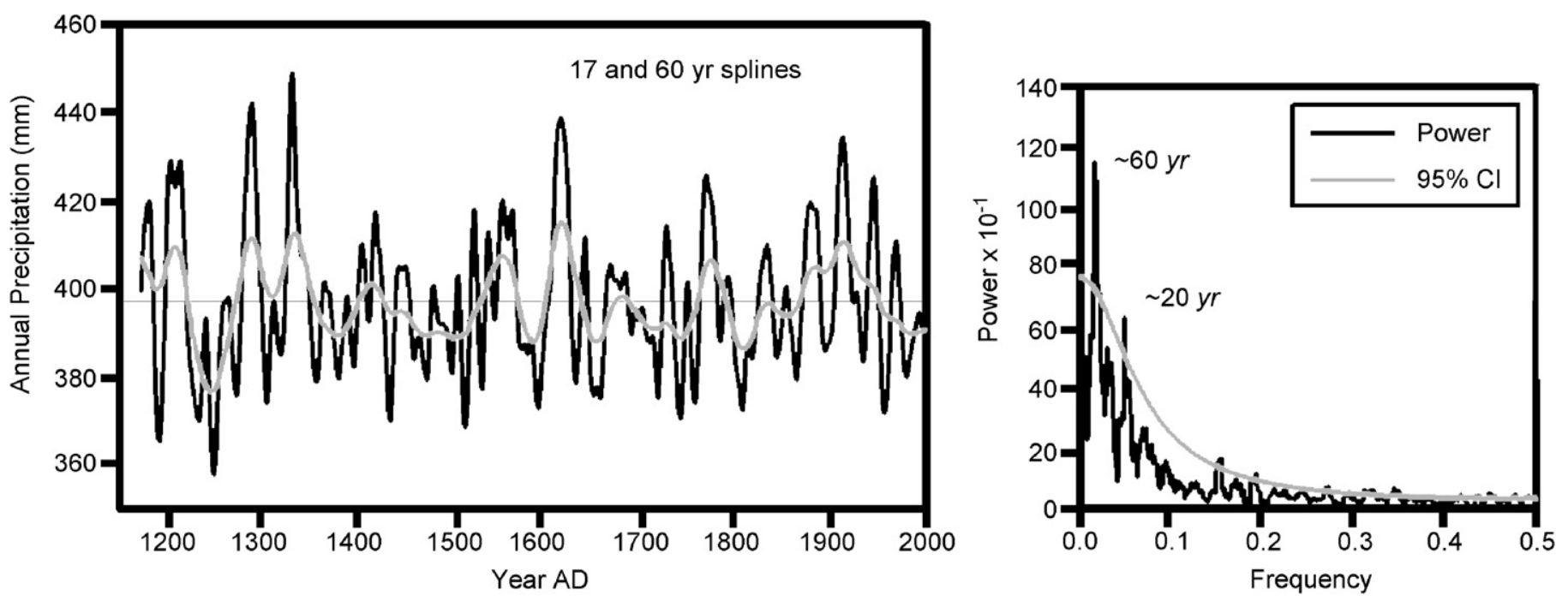

Fig. 1. Reconstruction of Yellowstone precipitation (820-year period) and spectral analysis of the time series (Gray et al., 2007). Decadal-to-multidecadal (D2M) variability is noticeable in this reconstruction. The spectral analysis indicates that the D2M variability is more significant than random red noise.

annual PDO, as well as detrended and smoothed annual Indian Ocean SSTs. The second set of PCs is strongly associated with the AMO. In all of these analyses Monte Carlo analyses were used to compute the statistical significance of the correlations. In all cases the correlations were found to be statistically significant at a $95 \%$ confidence level. The SVD analysis of the cross-covariance of the PDSI and SST data confirmed the close link between the PDSI and SST modes of decadal and multidecadal variation and provided a verification of the PCA results. These findings indicate that the major modes of multidecadal variations in SSTs and land surface climate conditions are highly interrelated through a small number of spatially complex but slowly varying teleconnections. These results also suggest that the D2M variability identified in McCabe and Palecki (2006) is not simply a result of statistical red noise, but is part of global climate variability.

There are a number of important reasons for examining and understanding D2M climate variability. For example, understanding what portion of climate variability is due to D2M variability allows the discrimination of anthropogenically caused changes in climate from natural variability. Understanding of D2M climate variability also has implications for defining and possibly predicting risks in agriculture, water resources, public health, and natural hazards. A growing number of studies also demonstrate the importance of D2M variability in controlling key physical and ecological processes (e.g. Swetnam and Betancourt, 1998; Pederson et al., 2004, 2006; Gray et al., 2006; Kitzberger et al., 2007).

\section{Variability of sea-surface temperatures and North American hydroclimate}

ENSO is an important source of inter-annual hydroclimatic variability in North America (Redmond and Koch,
1991). Persistent ENSO events also may be a source of D2M hydroclimatic variability (Seager et al., 2005). Schubert et al. (2004) and Seager et al. (2005) suggest that the 1930s drought in North America was primarily forced by cool SSTs in the eastern tropical Pacific Ocean (i.e. La Niña conditions). Fye et al. (2004) found that cool (warm) eastern tropical Pacific SSTs were associated with droughts (pluvials) in North America during the 20th century. Similarly, in a modeling study of 19 th century droughts in North America, Herweijer et al. (2006) suggest that these droughts were associated with La Niña conditions. A recent synthesis of North American drought over the last millennium also points to the dominating importance of cool "La Niña-like" SST's in the eastern tropical Pacific region (Cook et al., 2007).

Recently, research efforts have pointed to the Atlantic Ocean as a source of information to explain significant amounts of the D2M variability in North American, and possibly, global climate (Enfield et al., 2001; Gray et al., 2003, 2004; Sutton and Hodson, 2003, 2005; McCabe and Palecki, 2006). For example, the AMO has a strong relation to summer rainfall over the conterminous US, and may modulate the strength of the teleconnection between ENSO and winter precipitation (Enfield et al., 2001). Schubert et al. (2004) found that a warm Atlantic Ocean was important to properly model the Dust Bowl era precipitation deficits in the Great Plains. Low frequency changes in Atlantic SST anomalies also have been found to modulate ENSO effects on precipitation in southern Africa (Nicholson et al., 2001). In a study of North American precipitation and PDSI values for the 20th century, Booth et al. (2006) showed that the first PCs for each of these data sets are highly correlated with North Atlantic SSTs.

Recent studies by McCabe et al. (2004) and Hidalgo (2004) underscore the importance of the AMO for understanding changes in Western US drought status over the instrumental and proxy climate records of drought. 

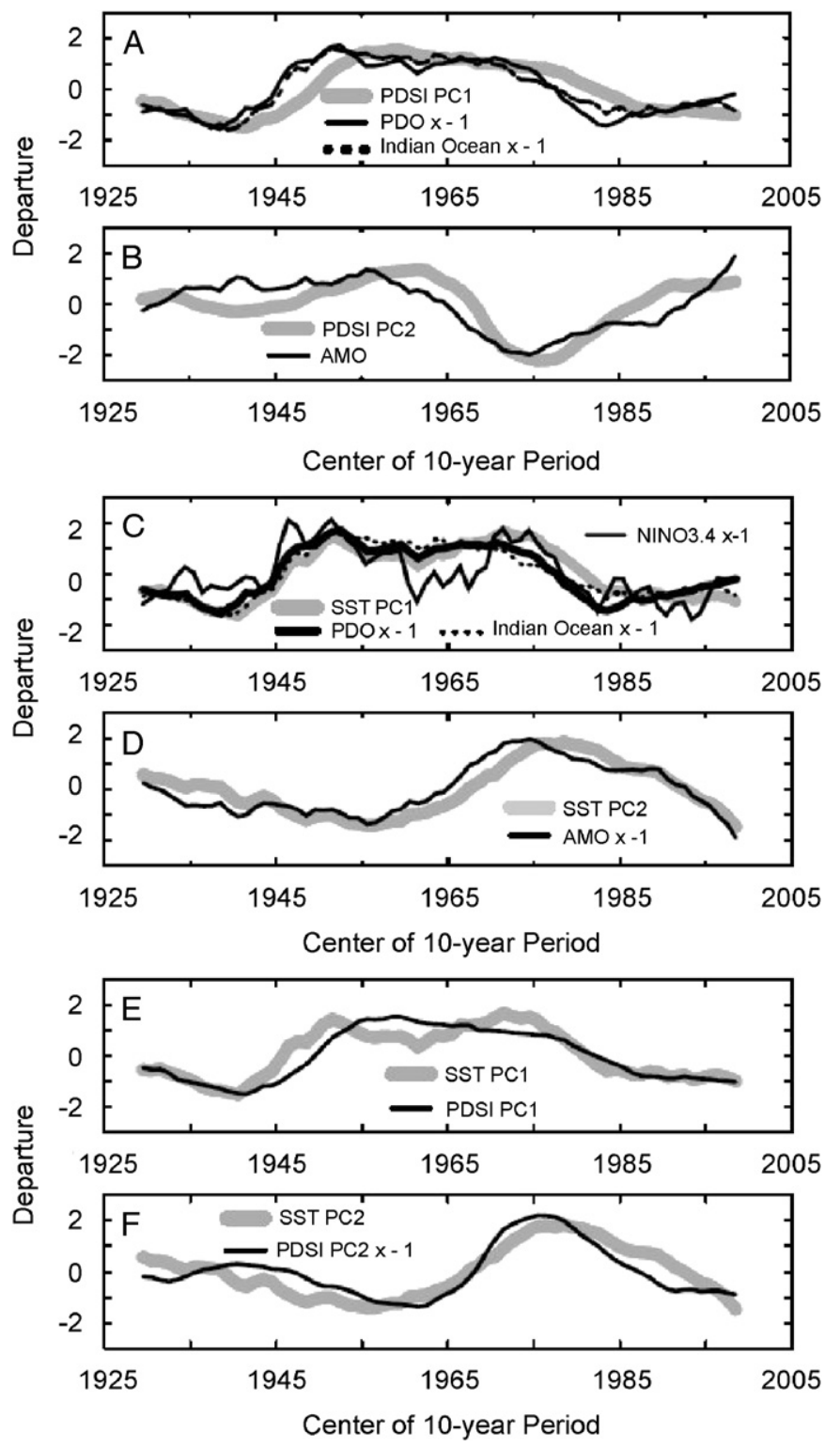

Fig. 2. Scores from principal components (PCs) analyses of detrended and 10-year smoothed global Palmer Drought Severity Index (PDSI) values (A and B) and global sea-surface temperatures (SSTs) (C and D) compared with time series of the Atlantic Multidecadal Oscillation (AMO), the Pacific Decadal Oscillation (PDO), Indian Ocean SSTs, and NINO3.4 SSTs. The PCs for global PDSI and global SSTs are directly compared in panels $(\mathrm{E})$ and $(\mathrm{F})$.

Multidecadal drought time series were derived in McCabe et al. (2004) by summing the number of times during a moving 20-year window that a conterminous US climate division had an annual precipitation value less than the 25th percentile for 1900-1999. These time series then were subjected to an unrotated PCA, yielding three major modes of spatio-temporal drought variance that were found to be extremely closely associated with the PDO, the AMO, and a temporal trend similar to hemispheric temperature change. The AMO drought signal was found to be the most coherent across the US; if the AMO was positive (negative), drought was more likely (less likely) in most of the US, especially the mountain West (Fig. 3). The PDO appears to act as a modifier of the AMO drought mode, focusing western drought in the northwestern US during positive $\mathrm{PDO} /$ positive AMO periods and focusing western drought in the southwestern US during negative PDO/ positive AMO periods (Fig. 3). Annual drought probabilities could as much as double given appropriate AMO and PDO signatures, a potentially useful relation for improving drought outlooks. Hidalgo (2004) confirmed the results of McCabe et al. (2004) with a study focused on the Western US exclusively, by using the 500 -yr records of the PDSI generated by Cook et al. (1999) as a basis for the drought PCA. Three rotated principal components corresponded to the PDO, AMO, and a smoothed time series of an indicator of ENSO status. In fact, while the amplitude of the PDO and ENSO linked western US drought modes varied somewhat through time, the AMO related drought mode seemed to be markedly steady in its oscillations over the 500-yr period. The one exception is the 18th century, when drought variability in the western US shifted from multidecadal (32-64 yr) to bidecadal (8-32 yr) and from subcontinental to regional (mostly the Southwest) in scale, respectively.

Analysis of the major US droughts during the last century indicates that North Atlantic SSTs were warm in the $1930 \mathrm{~s}, 1950 \mathrm{~s}$, and in the drying trend that began in the late 1990s (Table 1). In contrast, both the early (1905-1920) and late 20th century (1965-1995) pluvials were associated with cool North Atlantic SSTs (Table 1). Findings suggest that SSTs in all oceans have some relation with US hydroclimate, but SSTs in the North Atlantic have shown the most consistent association on D2M time scales during the 20th century. However, during the 19th century the tropical Pacific seems to have had a more consistent association with drought (e.g. Herweijer et al., 2006).

In addition to analyses of the instrumental climate record, a number of paleoclimate studies also have identified relations between North American climate and variability of the North Atlantic Ocean. For example, in a study of climate conditions in the western US during the past seven centuries reconstructed from tree rings (Gray et al., 2003) found a link to North Atlantic SSTs that suggests that when the North Atlantic is warm the percentage of the western US that experiences drought conditions is elevated. In subsequent research Gray et al. (2004) exploited the relations found between North Atlantic SSTs and tree-rings from sites in the eastern US, the Mediterranean, and Europe to reconstruct a time series of the AMO. The reconstructed time series spanned the period from 1567 to 1990 , and was strongly correlated $(r=0.94)$ with 20th century records of the AMO. Analysis of this tree-ring based AMO reconstruction showed that the type of strong D2M variability observed in instrumental SST records has been a consistent feature of the North Atlantic for at least the past four and a half centuries. An interesting feature of the Gray et al. (2004) $\mathrm{AMO}$ reconstruction is the lack of multidecadal variability 
A

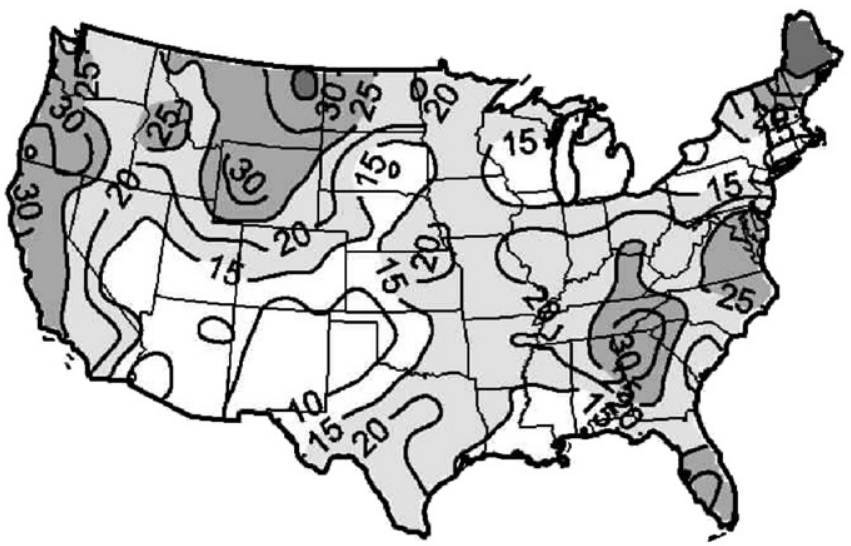

C

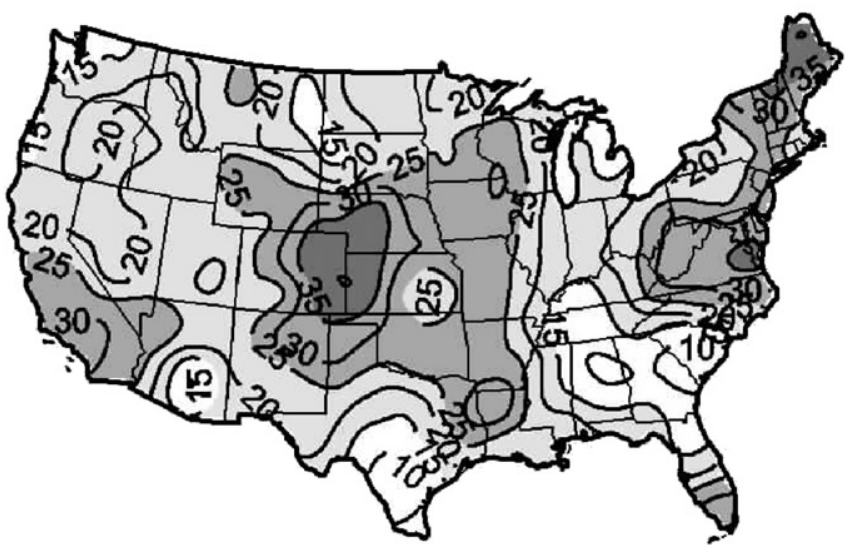

B

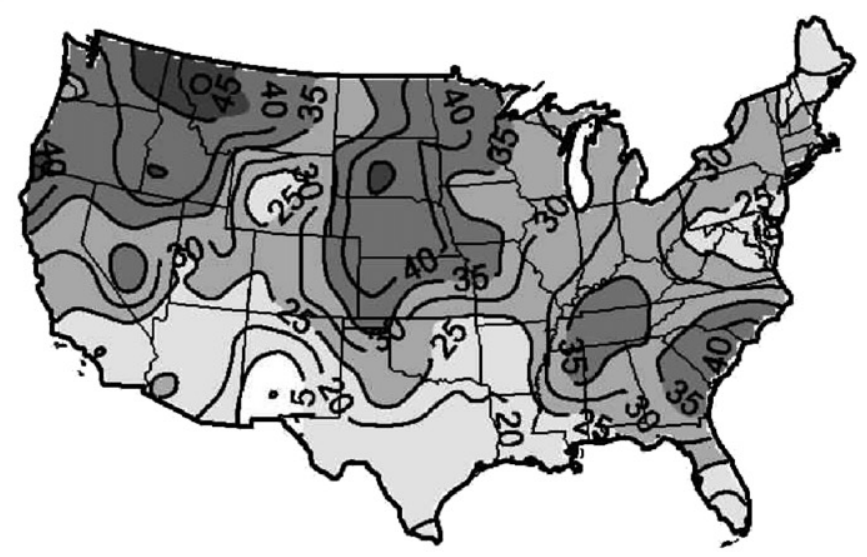

D

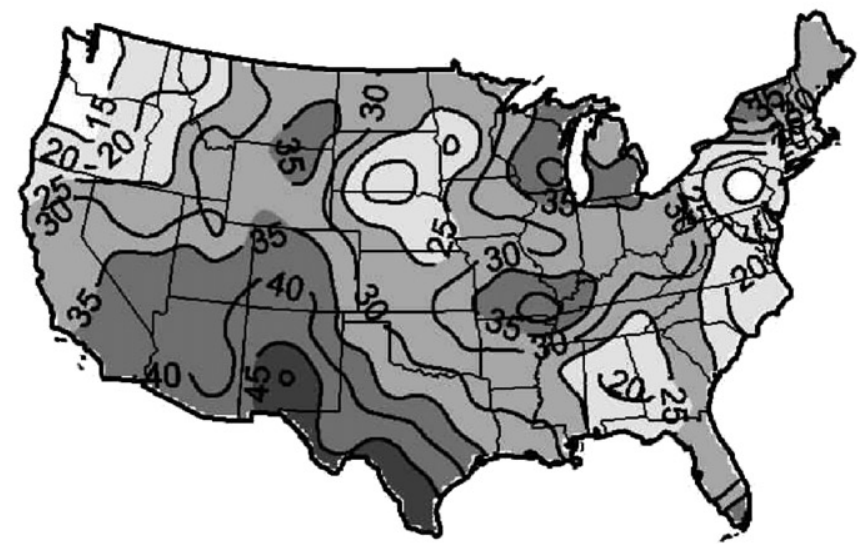

Fig. 3. Drought frequency (in percent of years) for positive and negative regimes of the Pacific Decadal Oscillation (PDO) and Atlantic Multidecadal Oscillation (AMO); (A) positive PDO, negative AMO, (B) negative PDO, negative AMO, (C) positive PDO, positive AMO, (D) negative PDO, positive AMO. Dark areas indicate regions with relatively high drought frequency and light areas indicate regions with relatively low drought frequency. Drought is defined as below the 25 th percentile of the distribution, so the long-term mean drought frequency is $25 \%$.

in the 18th century, in agreement with Hidalgo's (2004) observation for western US PDSI (Fig. 4). Based on comparisons of the AMO reconstruction against paleodroughts identified by Fye et al. (2003), 9 out of 10 major 1930s and 1950s style droughts (of at least 10 years in length) that occurred in North America between 1567 and 1990 coincided with warm North Atlantic SSTs (Fig. 4). Conversely, of the three major pluvials over this same period, all occurred during cool North Atlantic SST conditions (Fig. 4).

Sutton and Hodson (2005) recently performed a number of experiments with the Hadley climate model (HadCM3) to examine the effects of North Atlantic SSTs on the summer climate of North America and Europe. Their results provide evidence that basin-wide changes in the North Atlantic Ocean are an important driver of D2M variations in the summer climate of North America and Europe. They suggest that the D2M variability of the North Atlantic is related to the THC. In addition, the relations they report between the North Atlantic Ocean and North American climate are consistent with the findings of McCabe et al. (2004) obtained by analyzing observed climate records.
There have been recent and substantial efforts to model Atlantic SST forcing of the climate system at both interannual and interdecadal time scales. $\mathrm{Lu}$ and Dong (2005) demonstrated in a modeling study that the relative importance of Pacific and Atlantic tropical SSTs to the forcing of summer atmospheric circulation anomalies vary from year-to-year. They showed that the tropical circulation variations forced by Pacific SSTs were dominant during El Niño in 1997, while Atlantic SST forcing was much stronger than Pacific forcing in 1998, and propagated atmospheric circulation anomalies to all ocean basins. Zhang and Delworth (2006) recently demonstrated with a sophisticated atmosphere-ocean GCM with a fixed SST slab over the Atlantic that observed Atlantic Ocean temperatures alone can drive observed decadal scale dynamical forcing of Atlantic hurricane development and precipitation variations in the Sahel and India. Furthermore, Zhang et al. (2007) showed that the same modeling approach produced multi-decadal oscillations in northern hemisphere mean temperatures that were very similar to those observed with trend removed. Both of these findings have obvious implications for the forcing potential of the Atlantic Ocean that would be supportive of the work of 
Sutton and Hodson (2007), who clearly demonstrated the forcing of US temperature and precipitation by multidecadal variations in Atlantic SSTs.

The dynamics forced by an epoch of warmer Atlantic SSTs may be similar in some ways to those expected with future global warming. Basin wide increases in SSTs would expand the Hadley cell northward and decrease local moisture flux, reducing summer precipitation in southwestern North America (Seager et al., 2007) and, probably, all northern subtropical land areas. When the North Atlantic Basin alone is warmer than normal, a similar decadal-scale dynamical response would also be expected,

Table 1

Number of positive (pos $>0.5)$ and negative $(n e g<-0.5)$ values of standardized departures of annual NINO3.4 sea-surface temperatures (SSTs) and annual North Atlantic SSTs (averaged for the region $0-70^{\circ}$ North latitude and $10^{\circ}$ west to $60^{\circ}$ west longitude) for droughts and pluvials in the conterminous United States

\begin{tabular}{|c|c|c|c|c|}
\hline \multirow[t]{2}{*}{ Time period } & \multicolumn{2}{|c|}{ NINO3.4 } & \multicolumn{2}{|c|}{ North Atlantic SSTs } \\
\hline & Pos & Neg & Pos & Neg \\
\hline \multicolumn{5}{|l|}{ Droughts } \\
\hline $1856-1865$ & 2 & 3 & 3 & 1 \\
\hline $1870-1877$ & 1 & 6 & 1 & 0 \\
\hline $1890-1896$ & 1 & 4 & 1 & 2 \\
\hline $1931-1940$ & 2 & 3 & 6 & 0 \\
\hline $1929-1940$ & 4 & 3 & 7 & 0 \\
\hline $1951-1956$ & 0 & 3 & 4 & 0 \\
\hline $1946-1956$ & 0 & 6 & 4 & 0 \\
\hline 1999-2003 & 1 & 2 & 4 & 0 \\
\hline \multicolumn{5}{|l|}{ Pluvials } \\
\hline $1905-1920$ & 8 & 5 & 1 & 14 \\
\hline $1965-1995$ & 10 & 11 & 1 & 18 \\
\hline
\end{tabular}

The annual NINO3.4 and mean North Atlantic SSTs time series were detrended and subsequently standardized by dividing by the respective 1856-2005 mean and dividing by the respective 1856-2005 standard deviation. except when overwhelmed by interannual variability in the Pacific. It appears that most recent climate modeling studies that look at the effects of the Atlantic Ocean on interannual and interdecdal climate variability are finding a substantial, albeit non-exclusive role in the forcing of land climates around the world, including over North America.

\section{Possible underlying mechanisms for the associations of the North Atlantic Ocean with North American hydroclimate}

The actual physical mechanisms that explain the associations between the North Atlantic Ocean and the hydro-climate of North America are still unknown, but possible mechanisms include: (1) effects of North Atlantic SSTs on Northern Hemisphere atmospheric circulation such that the frequency of zonal versus meridional atmospheric flow over North America is modulated (Enfield et al., 2001). (2) D2M variability of North Atlantic SSTs may be aliasing for low-frequency and/or lagged variations of the tropical oceans (Latif, 2001). Modeling studies have indicated that low-frequency SST variability in the tropical Pacific may be the most significant source of D2M climatic variability (Seager et al., 2005), but may not operate independently of other oceans. In addition, it has been suggested that low-frequency variability of tropical Pacific SSTs is primarily driven by radiative forcing (Clement et al., 1996; Cane and Clement, 1999; Mann et al., 2005). (3) North Atlantic Ocean SSTs may be influencing the location and strength of sub-tropical high pressure (i.e. Bermuda High) and thus affecting the flow of moisture from the Gulf of Mexico into the US. Finally, (4) the North Atlantic Ocean may be modulating the strength and variability of tropical Pacific SSTs (Dong et al., 2006). A recent study using HadCM3 shows that multidecadal changes in Atlantic SSTs associated with THC overturning can modulate the variability of ENSO (Dong et al., 2006).

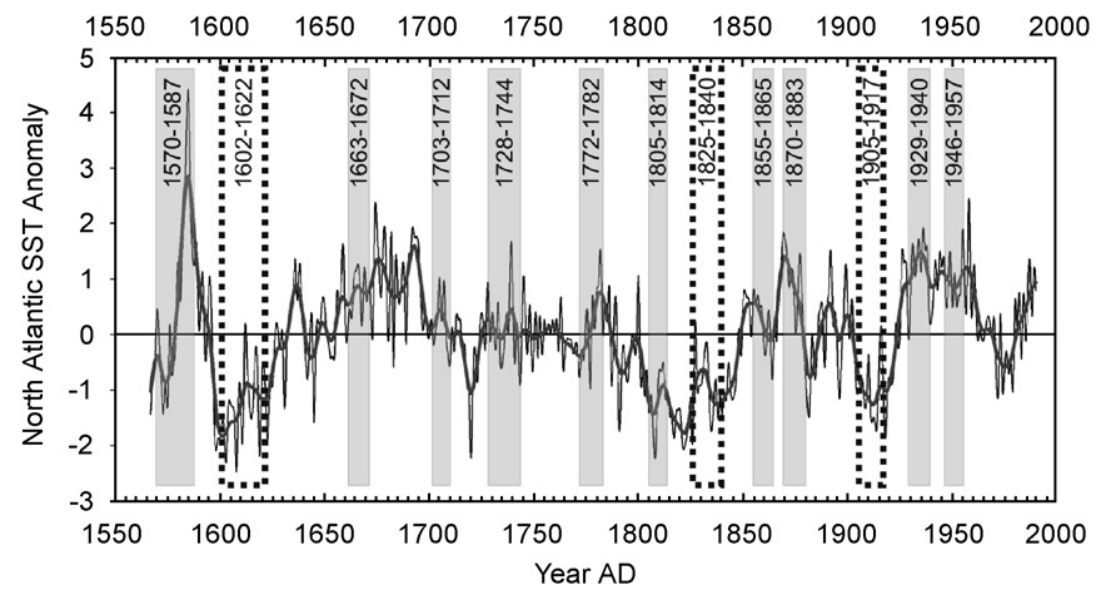

Fig. 4. Time series of reconstructed Atlantic Multidecadal Oscillation (North Atlantic Sea-Surface (SST) Temperature Anomaly, dimensionless, (black line)) with severe droughts (10 years or longer) indicated by gray bars, and pluvials (10 years or longer) indicated by dotted boxes. The reconstructed AMO is from Gray et al. (2004) and the droughts and pluvials are from Fye et al. (2003). 
One other possible explanation for the associations of North Atlantic SSTs with North American hydro-climate is that these statistical associations are happenstance. Additional modeling studies are needed to determine if these associations have physical meaning and whether they are independent from the influences of the tropical Pacific.

\section{Summary}

Mechanisms for inducing D2M signals in precipitation over land are poorly understood. Statistical and modeling studies suggest teleconnections to low-frequency SST variability in the Pacific, Indian, and North Atlantic Oceans (Hoerling and Kumar, 2003; McCabe and Palecki, 2006), and there is debate and mounting interest about mechanisms and predictability (e.g., Collins and Sinha, 2003). In the western US and Great Plains, correlation studies show consistent association of persistent droughts (pluvials) with North Atlantic warming (cooling) and tropical and eastern Pacific cooling (warming) (Enfield et al., 2001; McCabe et al., 2004; Schubert et al., 2004). Preliminary studies show similar relations between D2M variability in tree-ring reconstructions of precipitation (or the PDSI) with the PDO (e.g., Biondi et al., 2001) and the AMO (Hidalgo, 2004; Gray et al., 2004, 2006).

A review of previous research suggests that there are two primary hypotheses regarding the cause of drought in North America: (1) ENSO is the primary driver of D2M drought occurrence; and (2) interaction between the North Atlantic Ocean and ENSO drive drought occurrence. Additional modeling studies are needed to sort the relative influences and interactions (or non-interactions) of the tropical Pacific and Atlantic Oceans regarding drought occurrence in North America.

These previously published research results indicate that modes of multidecadal SST variation contain information that is useful for increasing the understanding of the climate system, identifying persistent climate regimes, and potentially improving seasonal climate forecasts. The utility of these multidecadal modes in adjusting base states for climate forecasting is currently being examined (Enfield and Cid-Serrano, 2006). Proximate causes aside, hydroclimatic persistence on these timescales introduces substantial non-stationarity in hydroclimatic conditions, with critical implications for water-resource management.

\section{Acknowledgments}

The authors would like to thank David Kristovich and James Angel for their helpful comments on early drafts of this paper. This work was partially supported by a National Oceanographic and Atmospheric Administration (NOAA) contract to the Midwestern Regional Climate Center. The views expressed in this document do not necessarily reflect those of the Illinois State Water Survey or NOAA.

\section{References}

Alexander, M.A., Deser, C., Timlin, M.S., 1999. The re-emergence of SST anomalies in the North Pacific Ocean. Journal of Climate 12, 2419-2431.

Allen, M.R., Ingram, W.J., 2002. Constraints on the future changes in climate and the hydrologic cycle. Nature 419, 224-232.

Booth, R.K., Notaro, M.N., Jackson, S.T., Kutzbach, J.E., 2006. Widespread drought episodes in the western Great Lakes region during the past 2000 years: geographic extent and potential mechanisms. Earth and Planetary Science Letters 242, 415-427.

Biondi, F., Gershunov, A., Cayan, D.R., 2001. North Pacific decadal climate variability since 1661 . Journal of Climate 14, 5-10.

Biondi, F., Kozubowski, T.J., Panorska, A.K., 2005. A new model for quantifying climatic episodes. International Journal of Climatology 25 , 1253-1264.

Bulic, I.H., Brankovic, C., 2006. ENSO forcing of the Northern Hemisphere climate in a large ensemble of model simulations based on a very long SST record. Climate Dynamics 28, 231-254.

Burke, E.J., Brown, S.J., Christidis, N., 2006. Modeling the recent evolution of global drought and projections for the twenty-first century with the Hadley Centre Climate Model. Journal of Hydrometeorology 7, 1113-1125.

Cane, M.A., Clement, A.C., 1999. A role for the tropical Pacific coupled ocean-atmosphere system on Milankovich and millennial timescales. Part II: global impacts. In: Clark, P.U., Webb, R.S., Keigwin, L.D. (Eds.), Mechanisms of Global Climate Change on Millennial Time Scales, vol. 112. AGU Geophysical Monograph, pp. 373-383.

Cayan, D.R., Dettinger, M.D., Diaz, H.F., Graham, N.E., 1998. Decadal variability of precipitation over western North America. Journal of Climate 11, 3148-3166.

Carton, J.A., Cao, X., Giese, B.S., Da Silva, A.M., 1996. Decadal and interannual SST variability in the tropical Atlantic Ocean. Journal of Physical Oceanography 26, 1165-1175.

Clement, A.C., Seager, R., Cane, M.A., Zebiak, S.E., 1996. An ocean dynamical thermostat. Journal of Climate 9, 2190-2196.

Cole, J.E., Cook, E.R., 1998. The changing relationship between ENSO variability and moisture balance in the continental United States. Geophysical Research Letters 25, 4529-4532.

Collins, M., Sinha, B., 2003. Predictable decadal variations in the thermohaline circulation and climate. Geophysical Research Letters 30, 1306.

Cook, E.R., Meko, D.M., Stahle, D.W., Cleaveland, M.K., 1999. Drought reconstructions for the continental United States. Journal of Climate $12,1145-1162$.

Cook, E.R., Woodhouse, C.A., Eakin, C.M., Meko, D.M., Stahle, D.W., 2004. Long-term aridity changes in the western United States. Science 306, 1015-1018.

Cook, E.R., Seager, R., Cane, M.A., Stahle, D.W., 2007. North American drought: reconstructions, causes, and consequences. Earth Science Reviews 1-2, 93-134.

Czaja, A., Frankignoul, C., 2002. Observed impact of Atlantic SST anomalies on the North Atlantic Oscillation. Journal of Climate 15, 606-623.

Dai, A., Wigley, T.M.L., 2000. Global patterns of ENSO-induced precipitation. Geophysical Research Letters 27, 1283-1286.

Dai, A., Trenberth, K.E., Qian, T., 2004. A global data set of Palmer Drought Severity Index for 1870-2002: relationship with soil moisture and effects of surface warming. Journal of Hydrometeorology 5, $1117-1130$.

Diaz, H.F., Markgraf, V. (Eds.), 2000. El Niño and the Southern Oscillation. Cambridge University Press, United Kingdom, 496pp.

Dima, M., Lohmann, G., 2007. A hemispheric mechanism for the Atlantic Multidecadal Oscillation. Journal of Climate 20, 2706-2719.

Dong, B., Sutton, R.T., Scaife, A.A., 2006. Multidecadal modulation of El Niño-Southern Oscillation (ENSO) variance by Atlantic Ocean sea surface temperatures. Geophysical Research Letters 33, L08705. 
Dong, B., Sutton, R.T., in press. Enhancement of El Niño-Southern Oscillation (ENSO) variability by a weakened Atlantic Thermohaline circulation in a coupled GCM. Journal of Climate.

Enfield, D.B., Cid-Serrano, L., 2006. Projecting the risk of future climate shifts. International Journal of Climatology 26, 885-895.

Enfield, D.B., Mestas-Nuñez, A.M., 1999. Multiscale variabilities in global sea surface temperatures and their relationships with tropospheric climate patterns. Journal of Climate 12, 2719-2733.

Enfield, D.B., Mestas-Nuñez, A.M., Trimble, P.J., 2001. The Atlantic multidecadal oscillation and its relation to rainfall and river flows in the continental. US Geophysical Research Letters 28, $277-280$.

FAO, 2004. The State of Food Insecurity in the World. Food and Agricultural Organization of the United Nations, Rome, Italy, 41pp.

FEMA, 1995. National Mitigation Strategy; Partnerships for Building Safer Communities. Mitigation Directorate, Federal Emergency Management Agency, Washington, DC.

Fontaine, B., Janicot, S., 1996. Sea surface temperature fields associated with West African rainfall anomaly types. Journal of Climate 9, 2935-2940.

Fye, F.K., Stahle, D.W., Cook, E.R., 2003. Paleoclimate analogs to 20th Century moisture regimes across the US. Bulletin of the American Meteorological Society 84, 901-909.

Fye, F.K., Stahle, D.W., Cook, E.R., 2004. Twentieth-century sea surface temperature patterns in the Pacific during decadal moisture regimes over the United States. Earth Interactions 8, 1-22.

Gershunov, A., Barnett, T.P., 1998. Inter-decadal modulation of ENSO teleconnections. Bulletin of the American Meteorological Society 79, $2715-2725$.

Giannini, A., Saravanan, R., Chang, P., 2003. Oceanic forcing of Sahel rainfall on interannual and interdecadal time scales. Science 302, $1027-1030$.

Goddard, L., Barnston, A.G., Mason, S.J., 2003. Evaluation of the IRI's "Net Assessment" seasonal climate forecasts: 1997-2001. Bulletin of the American Meteorological Society 84, 1761-1781.

Goodrich, G.B., 2007. Multidecadal climate variability and drought in the United States. Geography Compass 1.

Gray, S.T., Betancourt, J.L., Fastie, C.L., Jackson, S.T., 2003. Patterns and sources of multidecadal oscillations in drought-sensitive tree-ring records from the central and southern Rocky Mountains. Geophysical Research Letters 30, 1316

Gray, S.T., Graumlich, L.J., Betancourt, J.L., Pederson, G.T., 2004. A tree-ring based reconstruction of the Atlantic Multidecadal Oscillation since 1567A.D. Geophysical Research Letters 31, L12205.

Gray, S.T., Betancourt, J.L., Jackson, S.T., Eddy, R., 2006. Role of multidecadal climate variability in a range extension of pinyon pine. Ecology 87, 1124-1130.

Gray, S.T., Graumlich, L.J., Betancourt, J.L., 2007. Annual precipitation in the Yellowstone National Park Region since A.D. 1173. Quaternary Research 68, 18-27.

Griffies, S.M., Bryan, K., 1997. Predictability of North Atlantic multidecadal climate variability. Science $275,181-184$.

Gu, D., Philander, S.G.H., 1997. Interdecadal climate fluctuations that depend on exchanges between the tropics and extratropics. Science $275,805-807$.

Herweijer, C., Seager, R., Cook, E.R., 2006. North American droughts of the mid to late nineteenth century: a history, simulation and implications for mediaeval drought. The Holocene 16, 159-171.

Hidalgo, H.G., 2004. Climate precursors of multidecadal drought variability in the Western United States. Water Resources Research 40, W12504.

Hoerling, M., Kumar, A., 2003. The perfect ocean for drought. Science 299, 691-694.

Kiladis, G.N., Diaz, H.F., 1989. Global climatic anomalies associated with extremes in the Southern Oscillation. Journal of Climate 2, 1069-1090.

Kitzberger, T., Brown, P.M., Heyerdahl, E.K., Swetnam, T.M., Veblen, T.T., 2007. Contingent Pacific-Atlantic Ocean influence on multi-century wildfire synchrony over western North America. In: Proceedings of the National Academy of Sciences 104, 543-548.

Knight, J.R., Folland, C.K., Scaife, A.A., 2006. Climate impacts of the Atlantic Multidecadal Oscillation. Geophysical Research Letters 33.

Kousky, V.E., Kagano, M.T., Cavlcanti, I.F.A., 1984. A review of the Southern Oscillation: oceanic-atmospheric circulation changes and related rainfall anomalies. Tellus 36A, 490-502.

Latif, M., 2001. Tropical Pacific/Atlantic Ocean interactions at multidecadal time scales. Geophysical Research Letters 28, 539-542.

Lu, J., Vecchi, G.A., Reichler, T., 2007. Expansion of the Hadley cell under global warming. Geophysical Research Letters 34.

Lu, R., Dong, B., 2005. Impact of Atlantic sea surface temperature anomalies on the summer climate in the western North Pacific during 1997-1998. Journal of Geophysical Research 110, D16102.

Mann, M.E., Cane, M.A., Zebiak, S.E., Clement, A., 2005. Volcanic and solar forcing of the tropical Pacific over the past 1000 years. Journal of Climate 18, 447-456.

Mantua, N.J., Hare, S.R., Zhang, Y., Wallace, J.M., Francis, R.C., 1997. A Pacific interdecadal climate oscillation with impacts on salmon production. Bulletin of the American Meteorological Society 78, 1069-1079.

McCabe, G.J., Dettinger, M.D., 1999. Decadal variability in the strength of ENSO teleconnections with precipitation in the western United States. International Journal of Climatology 19, 1399-1410.

McCabe, G.J., Dettinger, M.D., 2002. Primary modes and predictability of year-to-year snow pack variations in the western United States from teleconnections with Pacific Ocean climate. Journal of Hydrometeorology 3, 13-25.

McCabe, G.J., Palecki, M.A., 2006. Multidecadal climate variability of global lands and oceans. International Journal of Climatology 26, 849-865.

McCabe, G.J., Palecki, M.A., Betancourt, J.L., 2004. Pacific and Atlantic Ocean influences on multidecadal drought frequency in the United States. Proceedings of the National Academy of Sciences 101, 4136-4141.

Newman, M., Compo, G.P., Alexander, M.A., 2003. ENSO-forced variability of the Pacific Decadal Oscillation. Journal of Climate 16, 3853-3857.

Nicholson, S.E., 1986. The spatial coherence of African rainfall anomalies: interhemispheric teleconnections. Journal of Climate and Applied Meteorology 25, 1365-1381.

Nicholson, S.E., Leposo, D., Grist, J., 2001. The relationship between El Niño and drought over Botswana. Journal of Climate 14, 323-335.

Pederson, G.T., Fagre, D.B., Gray, S.T., Graumlich, L.J., 2004. Decadalscale climate drivers for glacial mass balance in Glacier National Park, Montana, USA. Geophysical Research Letters 31, L12203.

Pederson, G.T., Gray, S.T., Fagre, D.B., Graumlich, L.J., 2006. Longduration drought variability and impacts on ecosystem services: a case study from Glacier National Park, Montana USA. Earth Interactions 10 (4), 1-28.

Peng, S., Robinson, W.A., Li, S., 2002. North Atlantic SST forcing of the NAO and relationships with intrinsic hemispheric variability. Geophysical Research Letters 29, 1276.

Rajagopalan, B., Cook, E., Lall, U., Ray, B., 2000. Temporal variability of ENSO-drought association in the southwest US. Journal of Climate 13, 4244-4255.

Redmond, K.T., Koch, R.W., 1991. Surface climate and streamflow variability in the western United States and their relationship to largescale circulation indices. Water Resources Research 27, 2381-2399.

Rodionov, S.N., 2006. Use of prewhitening in climate regime shift detection. Geophysical Research Letters 33, L12707.

Ropelewski, C.F., Halpert, M.S., 1986. North American precipitation and temperature patterns associated with El Niño/Southern Oscillation (ENSO). Monthly Weather Review 114, 2352-2362.

Ropelewski, C., Halpert, M., 1989. Precipitation patterns associated with the high index phase of the Southern Oscillation. Journal of Climate 2, 268-284. 
Schlesinger, M.E., Ramankutty, N., 1994. An oscillation in the global climate system of period 65-70 years. Science 367, 723-726.

Schubert, S.D., Suarez, M.J., Pegion, P.J., Koster, R.D., Bacmeister, J.T., 2004. On the cause of the 1930s dust bowl. Science 303, $1855-1859$.

Seager, R., Kushnir, Y., Herweijer, C., Naik, N., Velez, J., 2005. Modeling of tropical forcing of persistent droughts and pluvials over western North America: 1856-2000. Journal of Climate 18, 4068-4091.

Seager, R., Ting, M.F., Held, I.M., Kushnir, Y., Lu, J., Vecchi, G., Huang, H.-P., Harnik, N., Leetmaa, A., Lau, N.-C., Li, C., Velez, J., Naik, N., 2007. Model projections of an imminent transition to a more arid climate in southwestern North America. Science 0.

Shabbar, A., Skinner, W., 2004. Summer drought patterns in Canada and the relationship to global sea surface temperatures. Journal of Climate 17, 2866-2880.

Shindell, D.T., Schmidt, G.A., Miller, R.L., Mann, M.E., 2003. Volcanic and solar forcing of climate change during the preindustrial era. Journal of Climate 16, 4094-4107.

Siebold, J.S., Veblen, T.T., 2006. Relationships of subalpine forest fires in the Colorado Front Range with interannual and multidecadal-scale variation. Journal of Biogeography 33, 833-842.

Sutton, R.T., Hodson, D.L.R., 2003. Influence of the ocean on North Atlantic climate variability 1871-1999. Journal of Climate 16, 3296-3313.

Sutton, R.T., Hodson, D.L.R., 2005. Atlantic Ocean forcing of multidecadal variations in North American and European summer climate. Science 309, 115-118.

Sutton, R.T., Hodson, D.L.R., 2007. Climate response to basin-scale warming and cooling of the North Atlantic Ocean. Journal of Climate 20, 891-907.
Svoboda, M., LeComte, D., Hayes, M., Heim, R., Gleason, K., Angel, J., Rippey, B., Tinker, R., Palecki, M., Stooksbury, D., Miskus, D., Stephens, S., 2002. The drought monitor. Bulletin of the American Meteorological Society 83, 1181-1190.

Swetnam, T.W., Betancourt, J.L., 1998. Mesoscale disturbance and ecological response to decadal-scale climate variability in the American Southwest. Journal of Climate 11, 3128-3147.

Timmermann, A., Okumura, Y., An, S.-I., Clement, A., Dong, B., Guilyardi, E., Hu, A., Jungclaus, J.H., Renold, M., Stocker, T.F., Stouffer, R.J., Sutton, R., Xie, S.-P., Yin, J., in press. The influence of a weakening of the Atlantic meridional overturning circulation on ENSO. Journal of Climate.

Torrence, C., Webster, P.J., 1998. The annual cycle of persistence in the El Niño-Southern oscillation. Quarterly Journal Royal Meteorological Society 124, 1985-2004.

Torrence, C., Webster, P.J., 1999. Interdecadal changes in the ENSOMonsoon System. Journal Climate 12, 2679-2690.

Trenberth, K.E., 1997. The definition of El Niño. Bulletin of the American Meteorological Society 78, 2771-2777.

Walker, G.T., 1923. Correlation in seasonal variations of weather. VIII. A preliminary study of world-weather. Memoirs of the Indian Meteorological Department 24 (Part 4), 75-131.

Woodhouse, C.A., Overpeck, J.T., 1998. 2000 years of drought variability in the central United States. Bulletin of the American Meteorological Society 79, 2693-2714.

Zhang, R., Delworth, T.L., 2006. Impact of Atlantic mutidecadal oscillations on India/Sahel rainfall and Atlantic hurricanes. Geophysical Research Letters 33, L17712.

Zhang, R., Delworth, T.L., Held, I.M., 2007. Can the Atlantic Ocean drive the observed multidecadal variability in Northern Hemisphere mean temperature? Geophysical Research Letters 34. 